\title{
The Effect of Group Counseling (BKP) and Self-Efficiency on Improving Students' Social Skills in Junior High School 2 Tanjung Tiram
}

\author{
Abdul Munir \\ State University of Medan (Unimed), Medan, Indonesia \\ dr.abdmunir@gmail.com
}

\begin{abstract}
The aim of this study is to determine the effect of group counseling (BKP) on students' social skills. Knowing the effect of self-efficacy on students' social skills. Knowing the interaction between BKP and self-efficacy towards students' social skills. This study is a quasiexperimental study with factorial $2 \times 2$ design. The subjects of this study is $8^{\text {th }}$ grade student of Junior High School 2 Tanjung Tiram which amounted 43 students consisting of two class groups, where the first class as an experimental class was applied to BKP Modeling and the second class as a control class was applied to BKP Homeroom. The instrument used in this study is a questionnaire that is declared valid and reliable. Data are analyzed using two-way ANAVA analysis. From the results of the study it can be concluded that there is an effect of group counseling (BKP) on the social skills of students in Junior High School 2 Tanjung Tiram. There is a difference between BKP Modeling and BKP Homeroom in affecting students' social skills. There is no difference between low self-efficacy and high self-efficacy in affecting students' social skills. BKP Modeling is very good to use in improving students' social skills.
\end{abstract}

Keywords : modeling group counseling; self-efficacy; social skills.

\section{Introduction}

The results of observations and interviews with the counseling teacher. Information was obtained from Junior High School 2 Tanjung Tiram that students did not have the characteristics of sausage skills. This can be seen from the symptoms that appear to be bad speaking ethics, warmth that does not appear when interacting, and the absence of openness to one another. There are $80 \%$ of students who tend to be quiet when given the opportunity to ask questions in teaching and learning activities. Only $20 \%$ of students are able to communicate well and many students have difficulty communicating. Information was also obtained about group counseling services at Junior High School 2 Tanjung Tiram which were conducted in only one lesson in one week for each class. This is considered to be less intensive in its implementation. Group counseling should be carried out regularly and continuously.

Forming social skills can be done with counseling by parents at home or teachers at school. In school a counseling activity can be carried out individually or in groups depending on the complexity of the problem you want to solve. For the efficiency of counseling time can be done in groups. According to Wibowo (2005) group counseling is a group activity where group leaders provide information and direct discussion so that group members become more social or to help group members to achieve common goals. This was supported by the results of a study conducted by Atieka (2015) that group counseling services facilitated orphanages to learn to socialize, learn to solve problems, and respect themselves and others.

According to Corey (in Nurkhomisah, 2015) Behavioral group counseling approach is behavioral therapy which is the application of various techniques and procedures rooted in various theories about learning. This approach has provided a systematic application of the principles of learning and changing behavior towards more adaptive ways. According to Latipun (2006) modeling techniques can be used to shape new behavior in students, and can strengthen the behavior that has been formed. In this case counselor shows students about 
model behavior, can use audio models, physical models, life models or other observable and understood the type of behavior that would be emulated.

Modeling techniques can be used to shape new behaviors in students, and can strengthen established behavior. In this case the counselor shows students about model behavior, can use audio models, physical models, life models or other observable and understood types of behavior to be emulated (Latipun, 2006). Certain social skills can be obtained by observing and imitating the behavior of existing models. The emotional reactions that are disturbed by someone can be erased by the way the person observes other people who are approaching objects or situations that are feared without experiencing frightening consequences with the actions they take. Such controls can be learned through observations on models subject to punishment. The status and honor of the model is very meaningful and people are generally effectd by the behavior of the models that occupy a high status and are honored in their eyes as observers.

Based on the explanation on the counseling of the group, the behavioral approach to modeling techniques is group counseling with systematic behavioral therapy about the principles of learning and behavior change using a model that demonstrates the behavior that wants to be formed. In principle, therapy behavior itself aims to obtain new behaviors, eliminate old behaviors that damage themselves and strengthen, and maintain desired behaviors that are healthier. The aim of the behavioral approach to modeling techniques is to change behavior by observing the model to be imitated so that students reinforce established behaviors. According to Komalasari (2011) argues that the principles of modeling are as follows: (1) Learning can obtain through direct or indirect experience by observing the behavior of others along with the consequences. (2) Certain social skills can be obtained by observing and imitating existing model behavior. (3) Disturbed emotional reactions can be erased by observing other people who approach objects or situations that are feared without experiencing the frightening consequences of the actions they take. (4) Self-control is learned through observation of the model subject to punishment. (5) Honor status is very meaningful. (6) The individual observes a model and is strengthened to model behavior. (6) Modeling can be done with a model symbol through films and other visual tools.

The results of the Widaryanti (2013) study concluded that there was a positive effect on group counseling on self-efficacy. According to Baron (in Primary, 2013) self-efficacy is an individual's assessment of his ability or competence to do a task, achieve a goal, and produce something. Referring to the previous research and the theory above, it can be said that selfefficacy is effected by group counseling conducted at school. Previously it was also revealed that group counseling also effected social skills, thus it was assumed that there was an effect of self-efficacy on social skills. In this study, self-efficacy will be broken down into two, namely students who have high self-efficacy and students who have low self-efficacy. Then analyzed how it affects students' social skills. Besides the things revealed above, it will also be analyzed how the interaction between group counseling and self-efficacy in improving students' social skills. However, Khan (2013) in his research stated that self-efficacy does not affect teacher performance. In teacher performance requires social skills, thus Khan's conclusion states that self-efficacy does not affect social skills. It turns out that there are still differences in the results of research related to the effect of self-efficacy on sausage skills, so research needs to be done regarding this variable. 


\section{Research Methods}

This study was conducted in Junior High School 2 Tanjung Tiram. Jl. Manunggal V Ujung Kubu Village, Tanjung Tiram Sub district, Batu Bara District. This study is limited to $8^{\text {th }}$ grade students consisting of 6 classes which amounted 180 students. The subject were Class VIII-A as the first class and class VIII-B as the second class. The first sample class was treated with BKP modeling and the second sample class was treated with BKP homeroom.

This research type is quasi-experiment. The research design is used the pretest and posttest design. The study design was presented with a $2 \times 2$ factorial design with 2 -way analysis of variance analysis.

Table 1. Research Design of ANAVA 2 x 2

\begin{tabular}{|l|l|l|}
\hline \multirow{2}{*}{ Self-efficacy } & \multicolumn{2}{c|}{ BKP } \\
\cline { 2 - 3 } High & $\mathrm{KS}_{1}$ & $\mathrm{KS}_{2}$ \\
\hline Low & $\mathrm{KS}_{3}$ & $\mathrm{KS}_{4}$ \\
\hline
\end{tabular}

The steps taken are as follows:

1. The preparation phase of the study includes: making problem formulation, determining research variables, making literature studies to obtain the right theoretical bases of the research variables, determining and compiling and preparing instruments to be used in research and administrative management carried out by submitting a research permit from Medan Area Post Graduate Program.

2. The implementation phase begins with giving a self-efficacy questionnaire to the two study groups, namely the experimental class is consulted by BKP modeling and the control class is consulted by BKP homeroom. This questionnaire was given to find out which students have high self-efficacy and those who have low self-efficacy. Give a social skills questionnaire to get the pretest scores of both classes namely the experimental class and the control class. Counseling the experimental class and the control class as many as eight meetings with different treatments. Experimental class which is consulted by BKP modeling and control class which is consulted by BKP homeroom. The themes of each meeting are as follows: (1) Confidence, (2) Commenting, (3) Listening, (4) Permitting, (5) Responding, (6) Straightening, (7) Relationship, (8) Respect yourself and others. Provide a social skills questionnaire to get the posttest scores of both classes namely the experimental class and the control class. Inputting all questionnaires to the computer by using Microsoft Office Excel 2007 then transferring the data to SPSS for processing.

3. Before carrying out further data analysis the researcher did several things related to the data obtained from the research site. Among the activities carried out at the data analysis stage include: re-checking all data that has been collected, giving a score to the subject of research and providing a code of measurement results to facilitate data management and data analysis, tabulating scoring results and testing analysis with two-way analysis of variance (ANAVA) using the SPSS program. 


\section{Results and Discussion}

\subsection{Research Results}

The data description of the moderate self-efficacy variable is as follows:

Table 2. All Sample self-efficacy data

\begin{tabular}{|c|c|}
\hline Total & 43 \\
\hline Mean & 71,2 \\
\hline Std. Deviation & 8,42 \\
\hline Minimum & 54 \\
\hline Maximum & 92 \\
\hline
\end{tabular}

The SE value which is below the average value of SE 71.2 is included in the low category while the SE value that is above the average value of SE 71.2 is included in the high category. SE level grouping is used to divide learning outcomes test data into two categories in each sample class.

Table 3. Pretest Data of BKP Homeroom Class and BKP Modeling Class

\begin{tabular}{|c|c|c|c|c|c|}
\hline \multicolumn{3}{|c|}{ BKP Homeroom } & \multicolumn{3}{|c|}{ BKP Medeling } \\
\hline Score & $\mathrm{F}$ & Average & Score & $f$ & Average \\
\hline 34 & 3 & \multirow{8}{*}{36,27} & 33 & 5 & \multirow{8}{*}{35,48} \\
\hline 35 & 4 & & 34 & 3 & \\
\hline 36 & 5 & & 35 & 2 & \\
\hline 37 & 5 & & 36 & 3 & \\
\hline 38 & 4 & & 37 & 5 & \\
\hline 39 & 1 & & 38 & 2 & \\
\hline & & & 39 & 1 & \\
\hline Total & 22 & & & 21 & \\
\hline
\end{tabular}

Table 4. Posttest Data of BKP Homeroom Class and BKP Modeling Class

\begin{tabular}{|c|c|c|c|c|c|}
\hline \multicolumn{3}{|c|}{ BKP Homeroom } & \multicolumn{3}{|c|}{ BKP Medeling } \\
\hline Score & $\mathrm{f}$ & Average & Score & $\mathrm{F}$ & Average \\
\hline 39 & 1 & \multirow{9}{*}{42,59} & 46 & 1 & \multirow{9}{*}{50,95} \\
\hline 40 & 1 & & 48 & 1 & \\
\hline 41 & 2 & & 49 & 3 & \\
\hline 42 & 5 & & 50 & 3 & \\
\hline 43 & 8 & & 51 & 4 & \\
\hline 44 & 3 & & 52 & 4 & \\
\hline 45 & 2 & & 53 & 3 & \\
\hline & & & 54 & 2 & \\
\hline Total & 22 & & Total & 21 & \\
\hline
\end{tabular}

The comparison Data Average social skills based on the two-way ANAVA research design: 
Table 5. The Average of Social Skills Based on the Two-Way ANAVA Study Design

\begin{tabular}{|l|l|r|r|c|}
\hline BKP & Level SE & Mean & $\begin{array}{c}\text { Std. } \\
\text { Deviation }\end{array}$ & N \\
\hline BKP HR & Low & 42.7 & 1.25137 & 14 \\
\hline BKP HR & High & 42.2 & 1.83225 & 8 \\
\hline BKP Mdl & Low & 51.0 & 1.50504 & 12 \\
\hline BKP Mdl & High & 50.7 & 2.68225 & 9 \\
\hline
\end{tabular}

The results of the ANAVA Hypothesis test are presented in the following Table:

Table 6. The results of the ANAVA Test Both of Class

\begin{tabular}{|l|r|r|}
\hline Source & \multicolumn{1}{|c|}{ F } & \multicolumn{1}{c|}{ Sig. } \\
\hline Corrected & 77.499 & .000 \\
Model & 27588.5 & \\
Intercept & 23 & .000 \\
& 223.591 & .000 \\
BKP & .559 & .459 \\
LevelSE & .042 & .839 \\
BKP * & & \\
LevelSE & & \\
Error & & \\
Total & & \\
Corrected & & \\
Total & & \\
\hline
\end{tabular}

Based on the testing criteria / decision making using SPSS: Probability $<0.05$ (Santoso, 2005: 312). Means:

1. There is an effect of group counseling (BKP) on the social skills of students in Junior High School 2 Tanjung Tiram.

2. There is no effect of self-efficacy on the social skills of students in Junior High School 2 Tanjung Tiram.

3. There is no interaction between BKP and self-efficacy towards students' social skills.

Post Hoc Test Analysis with Tukey Test. The results obtained are presented in the following table:

Table 7. Results of Post Hoc Test Analysis with Tukey Test

\begin{tabular}{|l|l|c|}
\hline (I) Interaction & (J) Interaction & Sig. \\
\hline HR Low & HR High & 0.907 \\
\hline & Low Modeling & 0.000 \\
\hline & High Modeling & 0.000 \\
\hline & HR Low High & 0.907 \\
\hline & Low Modeling & 0.000 \\
\hline & High Modeling & 0.000 \\
\hline & HR Low & 0.000 \\
\hline & HR High & 0.000 \\
\hline & High Modeling & 0.980 \\
\hline
\end{tabular}




\begin{tabular}{|l|l|l|} 
High Modeling & HR Low & 0.000 \\
\hline & HR High & 0.000 \\
\hline & High Modeling & 0.980 \\
\hline
\end{tabular}

\subsection{Discussion}

The results of the study showed that students who were consulted using modeling group counseling scored an average of social skills of 50.95 while students who were consulted using homeroom group counseling scored an average of social skills of 42.59 . The results of the analysis of the variance of the significant value of the 0,000 class are smaller than the value of $\alpha=0.05$ so it can be concluded that there is a significant effect of group counseling on good social skills counseling.

Wibowo (2005) revealed group counseling is a group activity in which group leaders provide information and direct discussion so that group members become more social or to help group members achieve common goals. In a study conducted by Atieka (2015) concluded that group counseling services facilitated orphanages to learn to socialize, learn to solve problems, and respect themselves and others. Based on the theory and previous studies above it is assumed that group counseling will be able to effect and improve students' social skills.

Group counseling on the behavioral approach to modeling techniques and homeroom technical group counseling applied in two different classes. According to Corey (in Atmaja, 2016) the behavioral approach is behavioral therapy which is the application of various techniques and procedures rooted in various theories about learning. This approach has provided a systematic application of the principles of learning and behavior change towards more adaptive ways. According to Latipun (2006) modeling techniques can be used to shape new behaviors in students, and can strengthen established behavior. In this case the counselor shows students about model behavior, can use audio models, physical models, life models or other observable and understood types of behavior to be emulated. Furthermore, according to Prayitno (1995) homeroom can be interpreted as a technique of creating a family atmosphere that is used to hold meetings with a group of students both in the classroom and outside the classroom during class hours or outside the lesson hours to discuss some things that are deemed necessary especially in the field study, social, personal and career. In a study conducted by Widaryanti (2013) concluded that there was a positive effect on group counseling / counseling on self-efficacy. In other words group counseling will be able to form the skills desired by the supervisor.

Furthermore the results of the analysis of the variance of significant self-efficacy values of 0.459 are greater than the value of $\alpha=0.05$ so that it can be concluded that there is no significant effect of self-efficacy on students' social skills.

Based on the differences in previous studies; The first study conducted by Yunianti's (2016) that there were significant differences between the mathematics learning outcomes of group students who had high self-efficacy and students who had low self-efficacy in the base learning problem and cooperative learning model. Social skills are learning outcomes that are also expected to greet the learning process. Thus, Yunianti's (2016) study concluded that selfefficacy had a positive effect on students' social skills. Second, the research conducted by Khan (2013) in stating that self-efficacy does not affect teacher performance. In teacher performance requires social skills, thus Khan's conclusion states that self-efficacy does not affect social skills. The difference in the results of the two studies has been answered in this study that selfefficacy has no effect on sausage skills. 
Furthermore, the results of analysis of variance obtained a significant value of BKP * Level SE 0.839 greater than the value of $\alpha=0.05$, it can be said that the results of hypothesis testing accept $\mathrm{H}_{0}$ or reject $\mathrm{Ha}$ in the alpha level of $5 \%$, meaning there is no interaction between BKP and self- efficacy towards students' social skills.

First, the group of students consulted by BKP Homeroom who have low self-efficacy compared to BKP Homeroom which has low self-efficacy. Social skills of students who have low self-efficacy are not different results with students who have high self-efficacy on BKP Homeroom. This supports the study of Khan (2013) that self-efficacy has no effect on social skills. This explains that there is no significant effect of self-efficacy on Homeroom's BKP in affecting students' social skills for students with levels of low self-efficacy and high selfefficacy. This is because self-efficacy does not affect the improvement of students' social skills as previously explained.

Second, the group of students consulted by BKP Homeroom who have low self-efficacy compared to BKP Modeling which has low self-efficacy. Social skills of students who are consulted by BKP Modeling who have low self-efficacy are different from students consulted by BKP Homeroom who have low self-efficacy. This supports the Atieka (2015) study concluded that group counseling services affect students' social skills. This is due to the different treatment of the two groups. Self-efficacy does not affect students' social skills, but BKP Modeling has a greater effect than Homeroom's BKP. Differences in social skills occur due to the application of BKP Modeling.

Third, the group of students consulted by BKP Homeroom who have low self-efficacy compared to BKP Modeling which has high self-efficacy. Social skills of students who are consulted by BKP Modeling who have high self-efficacy are different from students consulted by BKP Homeroom who have low self-efficacy. This supports the Atieka (2015) study concluded that group counseling services affect students' social skills. This is due to the different treatment of the two groups. Self-efficacy does not affect students' social skills, but BKP Modeling has a greater effect than Homeroom's BKP. Differences in social skills occur due to the application of BKP Modeling.

Fourth, groups of students consulted by BKP Homeroom who have high self-efficacy compared to BKP Modeling which have low self-efficacy. Social skills of students who are consulted by BKP Modeling who have low self-efficacy are different from students consulted by BKP Homeroom who have high self-efficacy. This supports the Atieka (2015) study concluded that group counseling services affect students' social skills. This is due to the different treatment of the two groups. Self-efficacy does not affect students' social skills, but BKP Modeling has a greater effect than Homeroom's BKP. Differences in social skills occur due to the application of BKP Modeling.

Fifth, groups of students consulted by BKP Homeroom who have high self-efficacy compared to BKP Modeling have high self-efficacy. Social skills of students who are consulted by BKP Modeling who have high self-efficacy are different from students consulted by BKP Homeroom who have high self-efficacy. This supports the Atieka (2015) study concluded that group counseling services affect students' social skills. This is due to the different treatment of the two groups. Self-efficacy does not affect students' social skills, but BKP Modeling has a greater effect than Homeroom's BKP. Differences in social skills occur due to the application of BKP Modeling.

Sixth, groups of students who are consulted by BKP Modeling who have low selfefficacy compared to BKP Modeling which have high self-efficacy. Social skills of students 
who have low self-efficacy are not different results with students who have high self-efficacy on BKP Modeling. This supports the study of Khan (2013) that self-efficacy has no effect on social skills. This explains that there is no significant effect of self-efficacy on BKP modeling in affecting students' social skills for students with low levels of self-efficacy and high selfefficacy. This is because self-efficacy does not affect the improvement of students' social skills as previously explained.

\section{Conclusion}

Based on the results of data processing and discussion of the research conducted, conclusions can be drawn:

1. There is an effect of group counseling on modeling and homeroom techniques on the social skills of students in Junior High School 2 Tanjung Tiram. There are differences between the two, where the average social skills of BKP Modeling students are higher than the average BKP Homeroom. That is 50.95 with 42.59 .

2. There is no effect of self-efficacy on the social skills of students in Junior High School 2 Tanjung Tiram. The average sausage skills of students who have high self-efficacy are similar to low self-efficacy. That is 46.76 with 46.62 .

3. There is no interaction between BKP and self- on the social skills of students in Junior High School 2 Tanjung Tiram. It means that both of BKP and self-efficacy does not affect students' social skills.

\section{References}

Atieka, N. 2015. Self Efficacy Remaja Panti Asuhan dan Peningkatannya Melalui Pendekatan Bimbingan Kelompok. Jurnal Ilmu Pendidikan, Psikologi, Bimbingan dan Konseling. Volume 5 No 2 December 2015. ISSN 2088-9623

Atmaja, J.R. 2016. Tahapan dalam Bimbingan Konseling kelompok. http://jatirinakriatmaja.blogspot.co.id/2014/10/tahapan-dalam-bimbingan-dan-konseling.html (Accessed on march 2017)

Khan. 2013. Academic Self-Efficacy, Coping, and Academic Performance in College. International Journal of Undergraduate Research and Creative Activities

Komalasari, G. 2011. Teori dan Teknik Konseling, Jakarta : PT. Indeks.

Latipun. 2006. Psikologi Konseling. Malang: Universitas Muhammadiyah.

Nurkhomisah. (2015). Makalah Konseling Behavioral. https://nurukomisa. wordpress.com/2015/07/02/makalah-konseling-behavioral/ (Accessed on march 2017)

Prayitno. 1995. Layanan bimbingan dan Konseling Kelompok. Jakarta: Ghalia Indonesia.

Santoso, 2005. Metodologi Penelitian Kuantitatf dan Kualitatif. jakarta: Prestasi Pustaka.

Wibowo, M. E. 2005. Konseling Kelompok Perkembangan. Semarang: UNNES Press

Widaryati, S. 2013. Efektivitas Pengaruh Konseling Kelompok Terhadap Efikasi Diri Siswa. PSIKOPEDAGOGIA Jurnal Bimbingan dan Konseling 2013, Vol. 2, No. 2 ISSN : 23016167

Yunianti, E., Jaeng, M., Mustamin, 2016. Pengaruh Model Pembelajaran Dan Self-Efficacy Terhadap Hasil Belajar Matematika Siswa Sma Negeri 1 Parigi. e-Jurnal Mitra Sains, Volume 4 No. 1, January 2016 pp 8-19 ISSN: 2302-2027 